Copyright (C) 2021 by Cherkas Global University

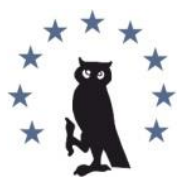

Published in the USA

Voennyi Sbornik

Has been issued since 1858 .

E-ISSN: 2409-1707

2021. 9(2): 100-104

DOI: $10.13187 /$ vs.2021.2.100

https://vs.cherkasgu.press

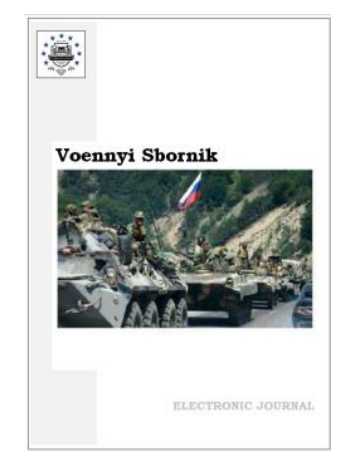

\title{
Dulesovo Timber Industry Enterprise during the Second World War in the Personnel Orders
}

Nicholas W. Mitiukov a , b , c, d, *

a Cherkas Global University, Washington, USA

b Udmurt Federal Research Center of the Ural Branch of the Russian Academy of Sciences, Izhevsk, Russian Federation

c Kalashnikov's Izhevsk State Technical University, Izhevsk, Russian Federation

${ }^{d}$ Moscow Institute of Psychoanalysis, Moscow, Russian Federation

\begin{abstract}
Sarapul timber industry enterprise - one of the oldest and largest forest enterprises in Udmurtia in its history has been reorganized more than once. In the period from 1938 to 1949 it was divided into several smaller farms, of which the fleet had only the Dulesovo mechanized forestry station. The source base on the work of this fleet during the war years is extremely limited. In the article, the reconstruction of the work of the fleet is carried out on the basis of orders for the personnel of the economy. The source falls under the law on the protection of personal data, which establishes 75 years, only after which, in 2020, the documentation became publicly available. At the beginning and end of the war, the fleet of the Dulesovo mechanized forestry station included a boat № 35 (3o hp) and one shitik (orlyana). An analysis of orders for wartime personnel showed extremely limited use of the existing fleet in the economy. Apparently, it was only by spring water that the ships were temporarily transferred to the Sarapul timber base for rafting, the rest of the time they were used for service and traveling purposes.

Keywords: timber industry, Sarapul district, Dulesovo mechanized forestry station, river transport, the Great Patriotic War.

\section{1. Введение}

Сарапульский леспромхоз - одно из старейших и крупных лесных хозяйств Удмуртии за свою историю неоднократно претерпевало переподчинения и реорганизацию. 14 августа 1938 г., на тот момент Сарапульский мехлесопункт (МЛП) был разделен на три самостоятельные единицы: Дулесовский. Ершовский и Мазунинский МЛП. Поскольку непосредственно сплавом на Каме занимался Дулесовский МЛП, ему передали флот Сарапульского МЛП. Хозяйство существовало до 29 июня 1949 г., когда в ходе очередной реорганизации Дулесовский, Ершовский и Камбарский леспромхозы (ЛПХ) снова объединили в Сарапульский ЛПХ с передачей ему флота Дулесовского ЛПХ. Таким образом, в годы Великой Отечественной войны из всех лесных хозяйств Сарапульского района УАССР только в Дулесовском МЛП имелся свой флот. Источники о работе этого флота крайне ограничены. Главной источниковой базой работы флота послужили приказы по личному составу хозяйства.
\end{abstract}

\footnotetext{
${ }^{*}$ Corresponding author

E-mail addresses: nicoo2@mail.ru (N.W. Mitiukov)
} 


\section{2. Результаты и обсуждение}

\section{Внешняя критика источника}

Приказы по личному составу Дулесовского МЛП представляют собой «амбарные» книги формата A4, с обложкой из обычного серого картона. Объем и состав их военного периода следующий.

Приказы директора Дулесовского мехлесопункта по личному составу Т. 1. (5 янв[аря] 15 авг[уста] 1940 г.). 105 л. (СГА. Ф. Р-231. Оп. За, Д. 24);

Приказы по Дулесовскому мехлесопункту Т. II. (26 июл[я] - 30 дек[абря] 1940 г.). 61 л. (СГА. Ф. Р-231. ОП. 3а, Д. 25);

Приказы директора Дулесовского мехлесопункта по основной деятельности и личному составу (3 янв[аря] - 24 сент[ября] 1941 г.). 136 л. (СГА. Ф. Р-231. Оп. За, Д. 48);

Приказы директора Дулесовского мехлесопункта по личному составу (26 сент[ября] 31 дек[абря] 1941 г.). 35 л. (СГА. Ф. Р-231. Оп. За, Д. 49);

Приказы директора Дулесовского мехлесопункта по личному составу (1 янв[аря] 30 дек[абря] 1942 г.). 48 л. (СГА. Ф. Р-231. Оп. за, Д. 64);

Приказы директора Дулесовского мехлесопункта по личному составу (2 янв[аря] 28 ноя[бря] 1943 г.). 91 л. (СГА. Ф. Р-231. Оп. За, Д. 76);

Приказы директора Дулесовского мехлесопункта по личному составу (3 янв[аря] 1944 г.- 24 мар[та] 1945 г.). 76 л. (СГА. Ф. Р-231. Оп. За, Д. 85).

Как видно, в 1940-41 гг. объем книг приказов составляет по 160 листов, достигая абсолютного минимума в 1942 г. (48 листов), после этого возрастает, но не так, как в 19401941 гг. Но это увеличение кажущееся. Если приказы 1940-42 гг. написаны в «амбарных» книгах промышленной сшивки, то начиная с 1943 г. листы книги представляют собой различные случайные листки, кустарной сшивки. Если быть корректным, то книги промышленной сшивки заканчиваются еще в ноябре 1942 г. и остаток книги этого года представляют собой неформатные и зачастую случайные листы: чертежи, счета и т.д. (Рисунок 1). Все это указывает на то, что, по крайней мере, с 1942 г. мехлесопункт стал испытывать дефицит бумаги. Как экономно ни расходовали бумагу в книге приказов, начатой в 1942 г. она все равно закончилась ближе к концу года. Кроме того, на использованных «случайных» листах обычно можно было писать лишь на одной стороне листа, что снижает объем приказов как минимум в два раза.

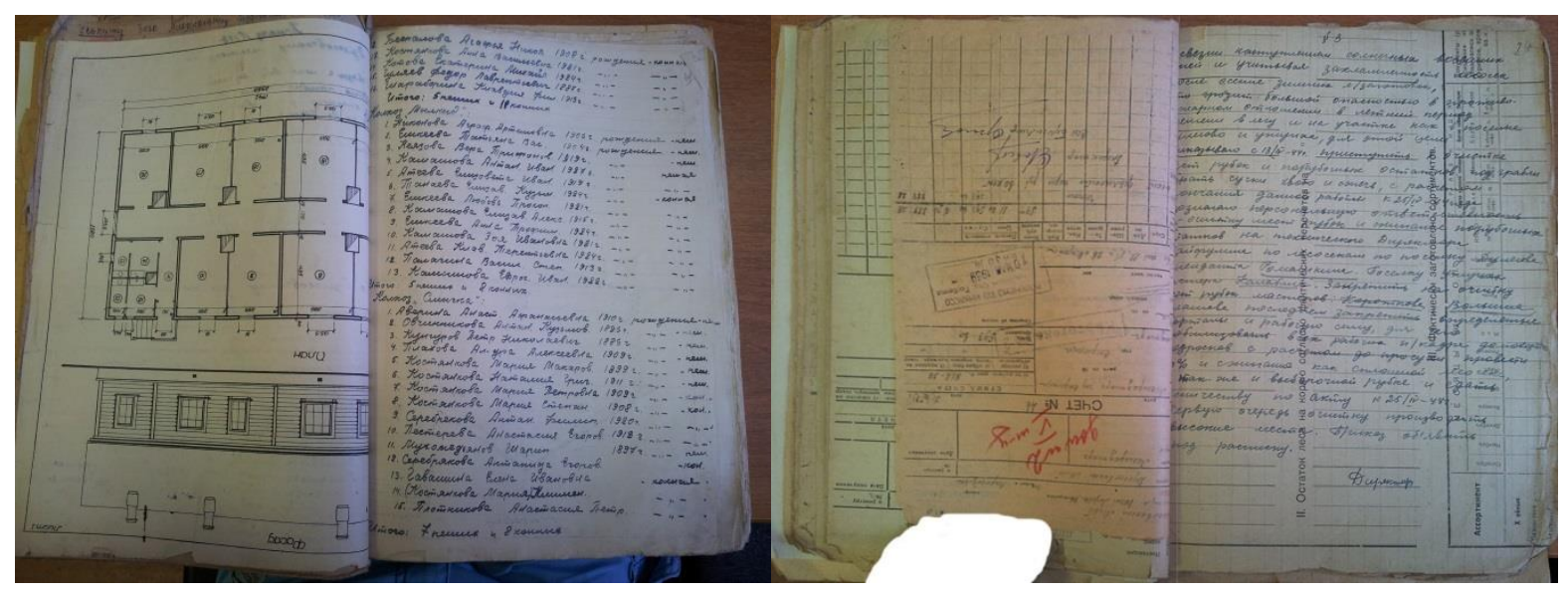

Рис. 1. Примеры «случайных» листов в книге приказов за 1942 г. (слева) и 1944 г. (справа)

Из-за дефицита бумаги несколько изменяются и содержание приказов. Если за 1940-1941 гг. они довольно подробно описывают все происшествия, обосновывая принятые организационные меры, то во время войны приказы в основном сводятся лишь к констатации кадровых перемещений. Крайней лаконичностью отличаются даже традиционные приказы о приближающемся ледоходе.

В целом, книги приказов написаны разными аккуратными почерками и разными чернилами. В конце каждого приказа стоит печать «директор», сопровождающаяся 
подписью действовавшего директора или исполняющего его обязанности. Она выполнена другим чернилами и явно другим почерком. Это указывает на то, что в мехлесопункте существовал штатный писарь.

\section{Краткий конспект источника}

Первое упоминание в приказах по личному составу относительно имеющегося в мехлесопункте флота, можно отнести традиционный приказ 3 апреля 1940 г. о возможной минимизации ущерба в ходе приближающегося ледохода. Среди прочих пунктов приказа указывалось: начальнику по транспорту «т. Черепанову обеспечить ремонт катера № 35 и Орляны для чего техснабу т. Марфину немедленно принять все меры для обеспечения необходимыми техматериалами и запчастями для ремонта катера» (СГА. Ф. Р-231. Оп. за. Д. 24. Л. 40 об).

Ввиду открытия навигации, приказом 27 апреля 1940 г. устанавливались месячные оклады команде катера. Рулевому П.Н. Мерзлякову - 350 руб., машинисту П.М. Азиатцеву 375 руб. До 24 апреля им начислялся межнавигационный оклад в размере 60\% от оклада (СГА. Ф. Р-231. Оп. За. Д. 24. Л. 53 об-54).

13 августа 1940 г. специальным приказом утверждались списки рабочих по мастерским и участкам. В отделе механика с непосредственным подчинением старшему механику состояли шофера, мотористы и т.д. Среди них значились рулевой Мерзляков Петр Николаевич, моторист Азиатцев Петр Максимович и шкипер Килин Ефим (вместо отчества стоит прочерк) (СГА. Ф. Р-231. Оп. За. Д. 24. Л. 100). Поскольку другие должности, скорее всего, с флотом не связаны, можно предположить, что команда катера состояла из двух человек, орляны из одного.

17 сентября 1940 г. из-за перевода на другую работу, мотористом катера стал Березкин Прокопий Иванович (СГА. Ф. Р-231. Оп. За. Д. 25. Л. 37 об). Но уже 15 октября из-за небольшого объема работ его перевели грузчиком (СГА. Ф. Р-231. Оп. За. Д. 25. Л. 39). А 15 ноября из-за закрытия навигации все команды судов перевели на другие работы (СГА. Ф. Р-231. Оп. За. Д. 25. Л. 49).

Вероятно, именно в этот небольшой период работы П.И. Березкин «отличился» кражей древесины объемом 2,57 фм, дело о которой в ноябре 1940 г. передали в суд (СГА. Ф. Р-231. Оп. за. Д. 25. Л. 48 об).

15 мая 1941 г. приказом по Дулесовскому мехлесопункту катер № 36 с 12 мая передавался вместе с командой (рулевой Мерзляков, моторист Азиатцев) в распоряжение Сарапульской лесобазы Наркомлеса УАССР на период проведения весеннего сплава и вывода древесины с реки Ужунки на лесобазу (СГА. Ф. Р-231. Оп. За. Д. 48. Л. 49). В самый разгар работы 1 июня 1941 г. рулевой катера прибыл на работу в пьяном виде, тем самым сорвав выполнение плана. За проступок виновному объявили строгий выговор (СГА. Ф. Р-231. Оп. за. Д. 48. Л. 73 об).

23 июня, уже на следующий день после начала войны, мехлесопункт проводил на фронт 30 своих работников, среди которых был и П.М. Азиатцев (СГА. Ф. Р-231. Оп. 3а. Д. 48. Л. 80).

А поскольку, вскоре призвали и П.Н. Мерзлякова, 29 августа вышел приказ о новом составе команды катера № 35. Его мотористом стал Вячкилев (?) Михаил Парамонович с месячным окладом 370 руб., а рулевым - Пономарев Иван Федорович с окладом 350 руб. В должности шкипера остался Е.А. Килин с окладом 250 руб. (СГА. Ф. Р-231. Оп. 3а. Д. 48. Л. 121). А уже приказом 4 октября мотористу объявили строгий выговор за появление на работе 24 сентября в нетрезвом виде (СГА. Ф. Р-231. ОП. За. Д. 49. Л. 3 об). По-видимому, несмотря на опьянение, он смог исполнять свои обязанности, иначе бы за прогул его дело непременно бы передали в суд.

Далее на зимний период в связи с окончанием навигации команду перевели на другие работы. И лишь с началом навигации приказом по мехлесопункту от 14 апреля 1942 г. был назначен новый состав команды: рулевой - П.И. Березкин (350 руб. в месяц), моторист В.Т. Волынин (370 руб.), шкипер - Е.А. Килин (3оо руб.) (СГА. Ф. Р-231. Оп. За. Д. 64. Л. 36). Таким образом, команда катера снова обновилась, а шкиперу увеличили оклад. 
8 мая 1942 г., как и в прошлом году, катер № 35 вместе с командой на основании распоряжения замнаркомлеса временно передавался в распоряжение Сарапульской лесобазы для выводки плотов (СГА. Ф. Р-231. Оп. За. Д. 64. Л. 42).

24 мая рулевой катера П.И. Березкин самовольно увел катер из Сарапула, оставив в городе нарочного П.И. Зюськевича, находящегося в служебной командировке, тем самым вызвав задержку в отправке секретной документации. За этот проступок рулевому объявили строгий выговор (СГА. Ф. Р-231. Оп. За. Д. 64. Л. 45).

Дальнейшие два года приказы по Дулесовскому мехлесопункту хранят молчание относительно своих судов. Лишь с 1 мая 1944 г. бывший мастер ледовой дороги П.И. Березкин назначался на должность рулевого катера со сдельной оплатой труда. Предполагалось, что он будет выполнять задания, согласно выданных путевок (СГА. Ф. Р-231. Оп. 3а. Д. 85. Л. 25).

18 мая катер мехлесопункта с орляной на буксире отправили в Каракулино за картофелем и гречкой, ранее полученными ОРСом. Для этой цели туда на катере командировали мастера Волынина. В свою очередь, П.И. Березкину ставилась задача самостоятельно спуститься на катере к Красному Бору и закупить там картофель, после чего в Шолье взять на борт гречку. Однако рулевой задание не выполнил, зато в Непряхе более часа простоял, чтобы повидаться со своими знакомыми. Получилось, что катер порожняком прогнали вниз и вверх по Каме. Приказом по мехлесопункту все расходы в размере 400 кг керосина, 4 кг бензина и 30 кг автола отнесли на счет П.И. Березкина (СГА. Ф. Р-231. Оп. 3 а. Д. 85. Л. 25-27). По-видимому, это происшествие стало крупным ЧП для мехлесопункта. Ему посвящено целых три страницы-листа в книге приказах, а само происшествие описывается два раза. Возможно, как следствие, с 1 июля 1944 г. И.Ф. Пономарева перевели на должность рулевого (СГА. Ф. Р-231. Оп. За. Д. 85. Л. 33). Но вскоре Березкин вернулся к исполнению своих обязанностей. И только 1 ноября, по окончании навигации, его перевели на должность мастера ледяной дороги (СГА. Ф. Р-231. Оп. За. Д. 85. Л. 64 об).

\section{Внутренняя критика источника}

Таким образом, как на начало войны (точнее на начало 1940 г.), так и на ее конец флот мехлесопункта включал в себя катер № 35 и орляну.

Весьма лаконичное содержание приказа относительно имеющегося в мехлесопункте флота, позволяет предположить, что он использовался крайне ограниченно. Если в Воткинском и Селычинском лесопунктах (леспромхозах) флот использовался по основному техническому назначению - для транспортировки леса, то в Дулесовском мехлесопункте для этой цели флот использовался лишь по вешней воде для сплава плотов. По-видимому, все остальное время имеющиеся катер и орляна применялись для служебно-разъездных целей.

\section{3. Заключение}

На начало и конец войны флот Дулесовского мехлесопункта включал в себя катер № 35 (3о л.с.) и один шитик (орляну). Анализ приказов по личному составу военного времени показал крайне ограниченное использование в хозяйстве имеющегося флота. По-видимому, лишь по весенней воде суда временно передавались Сарапульской лесобазе для сплава плотов, все остальное время используясь для служебно-разъездных целей.

\section{Литература}

СГА - Управление по делам архивов Администрации города Сарапула.

\section{References}

SGA - Upravlenie po delam arkhivov Administratsii goroda Sarapula [Department for Archives of the Administration of the city of Sarapul]. 


\section{Дулесовский леспромхоз во время Второй мировой войны в приказах по личному составу}

\section{Николай Витальевич Митюков a, b, c, d, *}

а Черкас глобальный университет, Вашингтон, США

ь Удмуртский федеральный исследовательский центр Уральского отделения

Российской академии наук, г. Ижевск, Российская Федерация

c Ижевский государственный технический университет им. М.Т. Калашникова, Ижевск, Российская Федерация

${ }^{\mathrm{d}}$ Московский институт психоанализа, Москва, Российская Федерация

Аннотация. Сарапульский леспромхоз - одно из старейших и крупных лесных хозяйств Удмуртии, за свою историю неоднократно реорганизовывалось. В период с 1938 по 1949 гг. оно было разделено на несколько более мелких хозяйств, из которых флот имел лишь Дулесовский мехлесопункт. Источниковая база о работе этого флота в годы войны крайне ограничена. В статье производится реконструкция работы флота на основе приказов по личному составу хозяйства. Источник подпадает под закон о защите персональных данных, устанавливающий 75 лет, только по истечении которых, в 2020 г. документация стала в открытом доступе. На начало и конец войны флот Дулесовского мехлесопункта включал в себя катер № 35 (3о л.с.) и один шитик (орляну). Анализ приказов по личному составу военного времени показал крайне ограниченное использование в хозяйстве имеющегося флота. По-видимому, лишь по весенней воде суда временно передавались Сарапульской лесобазе для сплава плотов, все остальное время они использовались для служебно-разъездных целей.

ключевые слова: леспромхоз, Сарапульский район, Дулесовский мехлесопункт, речной транспорт, Великая Отечественная война.

\footnotetext{
${ }^{*}$ Корреспондирующий автор

Адреса электронной почты: nicoo2@mail.ru (Н.В. Митюков)
} 